\title{
Topic B: Pesticide Resistance
}

\section{Insecticide Resistance}

\author{
島根大学生物資源科学部 尾添嘉久
}

このセッションでは，松村教授 (UCD) と Fitt 博士 (CSIRO) のオーガナイズによって, 殺虫剤抵抗性に関わる 5 題の講演と 活発な討論が行われた。害虫における殺虫剂抵抗性発現のメ力 ニズムを遺伝子・分子のレベルで説明できる時代がついに来た ことを実感させる講演が続いた。講演内容の概略は以下のとお クである。

1. Studies on Mechanisms of Insecticide Resistance in Blattella germanica (Fumio Matsumura, University of California, USA)

チャバネゴキブリ（Blattella germanica）を実験材料として 使って，2 種の殺虫剂抵抗性(シクロジエン殺虫剂抵抗性とピレ スロイド抵抗性)の分子機構を解明した. GABA レセプターRdl サブユニットの第 1 から第 4 膜貫通領域付近に相当する cDNAの塩基配列をシクロジエン殺虫剂抵抗性系統と感受性 系統の間で比較したところ，第 2 膜貫通領域の $\mathrm{N}$ 末端側（細胞 質側）のアミノ酸アラニンが抵抗性系統ではセリンに置換され ていた。一方，paraナトリウムチャネルのおおよそドメイン I セグメント 3 からドメイン IV セグメント 6 の間の cDNA 塩基 配列を比較したところ，ドメイン II セグメント 6 の中央付近の アミノ酸ロイシンがピレスロイド抵抗性 $k d r$ 系統ではフェ二 ルアラニンに変化していた。 これらの変異が抵抗性発現に関 わっていると考えられる。

変異が起こった部位が殺虫剂の作用点であるか，あるいは作 用点とは別の部位であるか，という2つのシナリオを想定する ことができる.GABAレセプターの場合は，アラニンからセリ ンへの変化によって作用点における極性と立体的障害が増し， その結果殺虫剤の結合が妨げられることが考えられる。十トリ ウムチャネルの場合は，各ドメインのセグメント 2 と 4 がチャ ネル内面を形成し，セグメント 6 はチャネルの外側に位置する という Sato-Matsumoto モデルなどから推察すると, 変異部位 は殺虫剤の結合部位ではない可能性が考えられる。この点の結 論を得るためには，さらにいろいろな角度からの研究が必要で ある。

2. Mechanisms and Diagnostic Procedures for Resistance Management of Insecticides (John M. Clark, University of Massachusetts, USA)

Colorado potato beetle (Leptinotarsa decemlineata (Say)) の有機リン殺虫剂アジンホスメチルに対する抵抗性が報告され
ている.ターゲットであるアセチルコリンエステラーゼ (AChE) の感受性低下がこの抵抗性発現の要因の1つである. アジンホスメチル抵抗性 (AZ-R) 系統では感受性系統 AChE の セリン 291 がグリシンに変化しており，これが感受性低下をも たらすと考えられる.シビレエイ AChEの構造に基づいて推察 すると, このアミノ酸は，三つ組触媒基と周縁院イオン部位と の間に位置する $\alpha$-ヘリックスの最初のアミノ酸に相当するの で, S291G の変異はアジンホスメチルオキソンの AChEへの結 合に影響を及ぼすと思われる。このほか AZ-R 系統の AChE は，基質阻害を受けない，かさ高い基質や阻害剤に対して負の 非感受性を示す，など興味深い特徴を持っている.

Colorado potato beetle $の$ AZ-Rのモニタリングに, cPASA (Competitive PCR Amplification of Specific Alleles) とこれを 改良したSSCP (Single-Stranded Conformational Polymorphism)/ミニシークエンス反応の $2 つ の$ DNA 診断法が利用で きる. 後者は, ミニシークエンス反応と ELISA 法を組み合わせ ることにより96穴マイクロタイタープレートを使って多くの 検体を同時に調べることができる方法である。

3. Naturally Occurring and Synthetically Enhanced OP Hydrolase from Insects（プログラムのタイトルは Mutations Enabling Insect Carboxylesterases to Hydrolyse Organophosphorus Insecticides; Charles Claudianos, CSIRO, Australia)

いくつかの昆虫の有機リン (OP) 殺虫剤抵抗性がカルボキシ ルエステラーゼ活性の低下と関係している。この抵抗性は, カ ルボキシルエステラーゼ活性を低下させ, OP 加水分解酵素活 性を生じさせる，カルボキシルエステラーゼの変異に基づいて いると考えられる(変異アリエステラーゼ仮説).キンバエ (Lucilia cuprina) では, 2つの夕イプ（ダイアジノンタイプと マラチオンタイプ）の OP 殺虫剂抵抗性がアリエステラーゼ (E3アイソザイム) 活性の低下と関連している.OP 殺虫剂抵抗 性系統と感受性系統のエステラーゼ E3 をコードする対立遺伝 子を比較して，いくつかのアミノ酸置換を明らかにした. ダイ アジノンタイプでは, 活性中心に存在すると思われるグリシン 137 のアスパラギン酸への変異が抵抗性発現と関連していると 思われる.この変異は, イエバエ Rutgers ダイアジノン抵抗性系 統でも認められた。一方マラチオンタイプでは, トリプトファ ン 251 のロイシンへの変異が抵抗性発現を引き起こしていると 考えられる，野外で採取した抵抗性系統・感受性系統キンバ工 の酵素と人工的に作製した変異酵素とを使って，変異を持たな い酵素はカルボキシルエステルを加水分解し, OP を加水分解 しないこと, 変異を持つ酵素は OP を加水分解し, カルボキシル エステルを加水分解しないことを示した。 
4. The Molecular Mechanism of Knockdown Resistance (David M. Soderlund, Cornell University, USA)

イエバエの para ナトリウムイオンチャネル遺伝子V Vssc1 が 単離された。Vssclの cRNA をアフリカツメガエル卵母細胞に 注入したところ, Vssc1 チャネルが発現し, 脱分極に応答してナ トリウムイオン電流が観察された。ショウジョウバエから単離 した補助タンパク質 TipE と共発現させたVssc1/TipE チャネ ルでは, 電流の増強とチャネルの機能変化が観察された. シス メトリンは, Vssc1/TipEチャネルに作用して, 脱分極している 間持続的な電流を生じさせ，再分極化した後大きな 2 相性の テール電流を生じさせた.シペルメトリンは持続的なテール電 流を生じさせた.

イエバエ 3 系統のV Vssl cDNA を比較したところ, ピレスロ イド抵抗性イエバエ $k d r$ 系統では, Vssc1ナトリウムイオン チャネルのロイシン 1014 がフェニルアラニンに変化していた. また super-kdr 系統では，これに加えてメチオニン 918 がトレ オニンに変化していた. L1014F 変異は, シスメトリンに対する Vssc1/TipE チャネルの感受性を 10４0 倍低下させただけでな く, シスメトリンが作用したチャネルの機能にも影響を及ぼし た。 シペルメトリンに対しては, 感受性の低下とテール電流減 衰の加速が観察された。 M918T/L1014F あるいは M918T 変異 を持つチャネルが生じるナトリウムイオン電流は高濃度の両ピ レスロイドの影響を受けなかった。

5. Mechanisms of Insecticide Resistance Development in House Flies: Unusual Sex-linked Expression of GST (Naoki Motoyama, Yukiko Sekine, and Risa Yamada, Chiba University, Japan)

殺虫剂抵抗性に関わる主要な代謝酵素としてシトクローム P450 モノオキシゲナーゼ, エステラーゼ, グルタチオン S-トラ ンスフェラーゼ (GST) が知られている. 有機リン殺虫剂抵抗 性イエバエ Cornell-R 系統から, 殺虫剂分解活性を有するアル カリGST アイソザイム 3 種を精製し, そのうちの 2つ (GST1 と GST3）について $\mathrm{N}$ 末端アミノ酸配列を決定した。この配列 は,これまでに報告された Cornell-R 系統イエバエの GST 遺伝 子の塩基配列から予想されるアミノ酸配列とは違っていたが, 最近新たにデータベースに登録された配列と同じであった. 従って, この 2 つ抵抗性発現にかかわる GST アイソザイム である.

無淘汰で長期間維持した殺虫剂抵抗性イエバエ第 3 夢の島 (3rd-Y) 系統の雄の GST 活性は此の活性に比べて異常に高い. GST 活性の連鎖群解析を行った結果, 雄の高 GST 活性は第 2 染色体上の因子に支配されていること，3rd-Y 系統では雄決定 因子（M 因子）が $\mathrm{Y}$ 染色体から第 2 染色体に転座していること が明らかになった，さらにこれまでに報告されている GST ア イソザイム遺伝子の発現量を雌雄間で比較したところ，上記ア イソザイムの場合においてだけ, 雄のほうが雌より活性が高 かった. 以上の結果は, 第 2 染色体に転座した $\mathrm{M}$ 因子が GST 遺 伝子の発現調節に影響して, mRNAの過剰転写とその結果とし ての GST タンパク質の過剩発現を引き起こしていることを示 唆している。

\section{Herbicide Resistance}

\section{農業環境技術研究所植生管理科 伊藤一幸}

本会議 (2nd Pan-Pacific Conference on Pesticide Science) は, アメリカ化学会の農薬部門 (American Chemical Society, Division of Agrochemicals) と日本農薬学会の共催で, 第 1 回 は 1996 年に神戸で開催され, 今回が 2 回目となる.

会議は世界で最も有名なワイキキの浜辺が見えるリゾートの 中心にある高級ホテルで 1999 年 10 月 24 日〜27 日の 4 日間に わたって開催された.この時期, 多少の通り雨はあったが寒く も暑くもない良い気候で,「今年の会議はカジュアルな格好で参 加してください」と案内書に書いてあり, せっかく日本から背 広やネクタイを持ってきたのに，まったく役に立たなかった。

配布されたりストによると, 国別参加者数はアメリカ合衆国 88 名, 日本 48 名, ドイツ 8 名, イギリス 7 名, 韓国 5 名, オー ストラリア 4 名, カナダ 4 名, その他のアジアー太平洋諸国等か ら 6 名と合計 170 名であった. 日本からの参加者の所属は民間 企業(研究所を含む) 17 名, 国公立研究所 15 名, 大学関係者 13 名, その他 3 名といろいろな組織からの参加が特徴であった.

会議は, 初日の朝食会を兼ねた基調講演, 3 日間 2 会場に分か れた分科会, 2 回に分けたポス夕ー発表, そして閉会セッション という構成であった。内容は, 農薬の合成, 代謝, 分析法, 環 境影響から殺虫剂抵抗性害虫・除草剂抵抗性雑草・殺菌剂耐性 病原菌, さらには除草剂耐性作物（遺伝子組換之作物）まで, 幅広い分野からの発表があった。

招待講演ではまず，カリフォルニア大学のJ. E. Casida 氏が 農薬の作用点について紹介した. 氏は現在, 限られた作用点に あまりにも多くの農薬が偏在していることが問題であるとし， 新規作用点探索の重要性を指摘した．特に作用点を，1）農薬の 一次・二次の作用点，2）哺乳類もその作用点を有しているが， 生理的に選択性がある農薬，3)複雑な代謝系における単一作用 点を有する農薬の 3 つに分類した。除草剂ではプロトックス阻 害剂を2)に，アミド系除草剂を 3) に位置付けていた. 後者に ついては，アミド構造からキノン類 (Quinonimine) に代謝され ることで，作用が発現している可能性を示唆した。

次に, 藤田稔夫氏が, 構造活性相関の環境毒性への応用につ いて提言した. 特に, 土壤吸着係数, 生物濃縮, 水生生物に対 する毒性について，水一オクタノール分配係数（Log P) との直 線的関係を強調した。

2 日目の午前中には遺伝子組換之作物のセッションがあっ た. 神戸大学の大川秀郎氏は, P450の選択的代謝について, 対 象農薬以外の農薬等に対する影響も合わせて調べる必要性を述 べた.すなわち，P450は異物を含む生体内の低分子有機化合物 を代謝する能力を備えているため, その基質特異性をしっかり 把握することが重要であると指摘した。

2 日目午後の環境科学および残留分析の分科会では, イムノ アッセイについて, ヤトロンの三宅司郎氏とハワイ大学の Q. X. Li 氏から紹介があった. 三宅氏はモノクローナル抗体を用 いて検出感度の高いイムノアッセイ法の開発について紹介し 
た. 数種除草剂について既に同アッセイ法が開発されており， 今後雑草防除の各分野への応用が期待される.

除草剂抵抗性のセッションは最終日の 10 月 27 日の午前にあ ク，他のセッションが同時に開催されたことと，すでに相当の メンバーがエスケープしたとみえて, 50 人前後に減ってしまっ たが熱心に論議した。

このセッションは農業研究センターの與語靖洋氏とバージニ ア州立大学の Hatzios 氏とがセッションオーガナイザーであっ た. 最初の発表は殺虫剂抵抗性の分科会に入りきらなかった話 題であるが, 除草剂抵抗性とも同じ考え方が取れる内容であっ たので紹介する。

オーストラリア国際機関 CSIROの G. P. Fitt 氏は，棉におけ る殺虫剂抵抗性害虫の出現までの期間と薬量との関係を調べ た. 同種の感受性外来害虫がない場合は，薬量が高くなるほど 抵抗性の出現までの期間が短縮される。一方，感受性外来害虫 が飛来してくる場合は, 薬量を上げると途中までは, 外来害虫 がない場合と同様に出現期間が短縮されるが，薬量をさらに上 げるとむしろ抵抗性出現までの期間が長くなるという事実を見 出した。 氏によれば，出現期間が再び長くなる薬剤濃度は，抵 抗性生物の薬量一反応曲線の $\mathrm{S}$ 字曲線部分に相当し, そのこと が要因であると推測した。一方，これまで除草剤抵抗性雑草の 研究分野では, 単純に種子や花粉の飛散だけを考えていたが, 抵抗性と感受性の混合集団では動向を考え直す必要性を感じ た.

さて, 除草剂抵抗性雑草の話題であるが，アメリカンサイア ナミッドの D. Sharner 氏（K. Hatzios 氏が代理で話をした）は, アメリカ合衆国でこれまでにアセト乳酸合成酵素（ALS）阻害 系除草剂に対する 26 種類の抵抗性雑草（単子葉 11 草種, 双子 葉 15 草種)が見つかっていること，また除草剤耐性の組換体大 豆の台頭により，イミダゾリノン系およびスルホニルウレア系 除草剂の使用量が減少し，それに伴い抵抗性雑草の出現も頭打 ちになってきていることを示した。 また，抵抗性雑草出現の要 因として，1）単作，2）同一除草剂の連年使用，および 3) 除草 剂に依存しすぎた雑草管理の 3 つを挙げた。

Adelaide 大学の C. Preston 氏 (オーストラリア) は, Lolium rigidum (ボウムギ) の除草剂複合抵抗性について発表した. 生 物型によってその複合抵抗性の程度は異なるが, VLR-69とい う生物型は, 驚くべきことに, ALS 阻害剤(スルホニルウレア, イミダゾリノン), 光合成阻害剂 (トリアジン, ウレア), 脂質 生合成阻害剂, カーバメート，アミド，いわゆるアセチル CoA

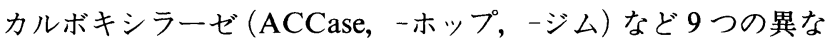
る化学構造の系統に対して抵抗性があった。 またChlorotoluron はオーストラリアで最近上市されたばかりであるが，まだ使 用されていない場所でもすでに抵抗性生物型が見つかった。こ のことから，除草剂の連年使用が抵抗性の出現要因ではなく, もともと種内変異の中に除草剂に対する抵抗性遺伝子を持って いたと考えるのが自然である．このような複合抵抗性は少なく とも, ACCase と ALSの変異による作用点親和性の低下, およ び 4 つの解毒代謝能力向上の合わせて 6 つの耐性機構が想定で きるとしていた. その中で複合抵抗性を獲得している機構とし て，P450による代謝を取り上げ, 1-amino-benzotriazole(ABT), piperonyl butoxide (PBO), マラチオン等の阻害剂を用いた試
験により証明を試みていた。ここで興味のあることは，P450 阻 害剂と除草剂の組み合わせで，抵抗性雑草に対する生物効果の 回復程度が異なることである。その説明として，P450阻害剂に よって活性が低下する P450の種類が異なり,さらに P450のア イソザイムの代謝に基質特異性があるため，その組み合わせに より，除草剤の解毒代謝の程度が違ってくるとした。

Guelph 大学 J.C. Hall 氏（カナダ）は，ホルモン系除草剂抵 抗性雑草について, 吸収・移行・代謝ではなく, 作用点である エチレン生合成の制御, 特にオーキシン結合タンパク質への競 合的阻害が重要であるとした。

また ACCase 阻害剤について，K. Hatzios 氏は，ACCaseに は，葉緑体に存在する原核細胞的なものと，核に存在する真核 細胞的なものがあり, 後者は単子葉・双子葉の両方に存在して, アリルオキシフェノキシプロピオン酸類 (AOPP, 前述の-ホッ プ）に感受性であるのに対し，前者は双子葉植物にしか存在せ ず，AOPPに対して非感受性であることを報告した．結果とし て，広葉作物におけるイネ科専用の茎葉処理剤として適用性が あると考えられている．氏はその他の抵抗性機構として，細胞 膜の極性の変化, 薬剂代謝, ACCase の過剩生産 (Sorghum halepense，ハイキビ）などを挙げていた。また ACCase 阻害剂 の交差抵抗性について, 一ホップ類にはあるが, 同じ作用点であ るージム類にはないことも報告していた。

日本からの報告では與語靖洋氏がパラコートおよびシマジン 抵抗性畑雑草について研究史, 雑草の種類, 分布, 遺伝様式, 作用機作等に分けて分かりやすく説明した。 パラコート抵抗性 については渡辺泰氏, 埴岡靖男氏, 佐藤光政氏, 浅野紘臣氏, 山末祐二氏および筆者, シマジンについては大西忠男氏，故小 林央往氏になどのデー夕を用い，考え方を整理して述べた。

筆者はこれまで日本で自然に出現したスルホニルウレア系除 草剂抵抗性雑草 10 種について, 出現時期, それぞれの抵抗性生 物型の分布について述べた. また, 拡散要因, 乾田を好むといっ た生態, 遺伝様式, 分子生物学的知見, 変異部位のアミノ酸の 差違, 簡易検定法などについてアゼトウガラシを中心に述べた. さらに最近北海道や東北地域で見つかったイヌホタルイの抵抗 性生物型は水田の雑草防除を考える上で非常に重要な問題点で あり，また拡散のきざしもあり取り上げた．特に，北海道立農 試の古原洋氏らのグループによる抵抗性生物型の種子は低温で 発芽できる傾向にあるといった試験結果や，東北大学の吉岡俊 人氏らのグループによるALS 遺伝子の変異実態を含めて報告 した.これらの知見はまだ日本雑草学会で講演発表されたばか クの段階なので，口頭報告にとどめた.

除草剂抵抗性のセッションの総合討議において, 前述のC. Preston 氏はオーストラリアでグリホサート抵抗性のボウムギ が出現していることを報告した。 そこでは，15 年間不耕起栽培 をしており，グリホサートを連年使用しているとのことであっ た. ただ抵抗性機構についてはまだ解明されていない.マレー シアでグリホサート抵抗性オヒシバの出現の話題も著者は知っ ており，これらの抵抗性機構の解明が組換体作物との関係で急 がれる，その場では，除草剤耐性大豆におけるグリホサートの 連年使用に対する警鐘の必要性があるかについて多少ではある が議論された，莫大なお金の絡む話であり，議論が盛り上がっ た。 
表 1 講演会およびポスターセッションの分類

\begin{tabular}{lcc}
\hline \multicolumn{1}{c}{ 分類 } & 口頭発表 ${ }^{*}$ & ポスター発表 \\
\hline 農薬合成 & 3 & 7 \\
農薬の環境中挙動 & 4 & 14 \\
天然物化学 & 5 & 6 \\
農薬の代謝 & 5 & 0 \\
農薬の環境影響評価 & 6 & 4 \\
生物農薬と遺伝子組換え作物 & 5 & 1 \\
環境化学・残留分析 & 6 & 16 \\
殺虫剤抵抗性害虫 & 4 & 0 \\
農薬の混合化学 & 7 & 1 \\
除草剂抵抗性雑草 & 7 & 0 \\
殺菌剂抵抗性病原菌 & 6 & 4 \\
農薬の作用機構 & 4 & 2 \\
\hline \multicolumn{1}{c}{ 総 } & 62 & 55 \\
\hline
\end{tabular}

*：基調講演および会議の総括発表は含めていない。（與語 靖洋氏の集計による)

また，55のポスター発表があった。その中で著者が興味を 持ったものを 1 つだけ取り上げる.

アメリカUSDA の S. O. Duke 氏らのグループは，クマツッ゙ ラ科の一種である Callicarpa americana から抽出した油類に藻 類を含む植物に除草活性および抗菌効果があることを見出し た. 抽出した油を GC/MS で分析すると 67 種に分けられるが， どの成分に除草活性があるかはまだ特定できていないようであ る.11月になって農環研が主催した生物間の化学的応答のワー クショップに氏が来日したときは，アレロパシー作用の強い稲 品種についても同様な分析を示していた，天然物からの除草活 性の探査も少しずつ進展している.

その他除草剤の残留分析法や環境中挙動，また口頭発表に関 連したポスター発表がたくさんあったが，割愛する.

アメリカ, コンコルド研究センターの芳賀隆弘氏は, 今回の 会議を総括するとともに，農薬の将来像について，高活性剂の 開発として有効成分にしてへクタールあたり $1 \mathrm{~g}$ を目指すべき であることを強調した。

最後に本会議の議長である, 理化学研究所の山口勇氏と B. Cross 氏は次回開催について, 2003 年, 再び八ワイに集まるよう 提案して閉会した。本会議の報告は，アメリカ化学会からそれ ぞれテーマ別に 3 冊の分冊になって出版される予定であるとの ことで，未完成の原稿を置いてきた。

最後になりましたが，著者は日本農薬学会から国際会議出席 費の補助を受けて本会議に出席いたしました。この場をお借り して関係者の皆様に心より感謝申し上げます。

\section{Fungicide Resistance}

\section{農業環境技術研究所 石井英夫}

このセッションは，最終日の午後に開かれたことも災いして か, 参加者の少ない寂しいものであった、ヨーロッパや日本に 比べて, 殺菌剂耐性菌の研究者がアメリカではあまり多くない
ことも関係があろうか.

我々, セッションオーガナイザーは当初, 日米双方から 3 名 ずつのスピーカーを予定していたが，直前になってアメリカ側 の 2 名が出席をキャンセルしたため, 我が国から 4 名, アメリ カから 2 名ということになった，以下に，私見も交えて，発表 内容を紹介する。

トップバッターは，コーネル大学の Wolfram Koeller が務め, 最近各方面での関心が高い，ストロビルリン系殺菌剂 (STAR) 耐性菌について講演した. 本剂耐性菌は, 最初ドイツのコムギ うどんこ病で問題となったが, このところ日本でも，キュウリ のうどんこ病やべと病で，耐性菌によって薬剤の効果が低下す る事例が見られている。

Koeller は, リンゴ黒星病菌の感受性株から，クレソキシムメ チルとサリチルヒドロキサム酸 SHAM，代替呼吸系の阻害剂） を用いて，STARに耐性を示す実験室内変異株を取得した。 STAR の作用点とされる，電子伝達系のシトクロム b 遺伝子 を調べたところ，耐性菌では，推定されるアミノ酸の 1 つに置 換が見られた，現在実際に問題になっている，コムギうどんこ 病菌，キュウリのうどんこ病菌やべと病菌で，同様の 1 アミノ 酸置換が耐性に関与しているかどうかは，筆者の研究室も含め て，幾つかの機関で調べられている．その結果は，近いうちに 明らかにされるであろう。開発されて間もないSTARに，この ように速く耐性菌が出現した背景として， mtDNAであるシト クロム $\mathrm{b}$ 遺伝子の点突然変異を考えるのが最も妥当であるが, その他の機構，例えば代替呼吸活性の増大などが関与する可能 性も否定できない.STARは，天然物をリードとし，その防除 スペクトラムも群を抜いて広いことから，現在世界で最も期待 される殺菌剤である，それだけに，耐性菌問題の行方は大いに 注目される。もし，耐性菌の fitness が，感受性菌と大差がない ことにでもなれば，今後の病害防除のあり方にも大きな影響を 与えかねないからである。

次に, 東洋大学の藤村 真氏が, ジカルボキシイミド剤とフェ ニルピロール剂に関連して講演した。ジカルボキシイミド剂に ついては，灰色かび病菌などで，耐性菌が古くから知られてい る。一方，フルジオキソニルに代表されるフェニルピロール剂 は,その化学構造がジカルボキシイミド剂に類似することから， これらの薬剤グループ間で而性が一部交さするのではないかと の危惧もある。

アカパンカビの野生株では，これら薬剤の処理により浸透圧 安定化剂であるグリセロールの異常蓄積が起こるが，浸透圧感 受性 (os) 変異株では，この蓄積が認められない。しかし，グリ セロール合成欠損株が，野生株同様に薬剤に感受性を示したこ とから，グリセロールの異常蓄積の誘導が，抗菌作用に直接つ ながるとは考えられない.そこで，これらの薬剂は浸透圧シグ ナル伝達系に作用していると考えられるが，その作用機構は依 然不明である。

また，浸透圧センサ一遺伝子 (os- 1$)$ の変異株は，薬剤感受性 と浸透圧感受性の違いから, 2 種類に分けられる. 薬剂高度耐性 変異株は野生株に近い浸透圧感受性を示し（タイプI）, 浸透圧 に高い感受性を示す変異株の薬剤耐性程度はむしろ低い（夕イ プ II)。このjち，タイプ II の変異株 1 つについて，625Leu か ら 625Proへのアミノ酸置換が同定された。この変異は, 機能不 
明のアミノ酸リピートに位置している.

なお, os-1 変異以外の os 変異株が薬剤に高度耐性を示すのに 対して, os-1 変異株が, 薬剤耐性, 浸透圧感受性において多様 性を示すことから, 固場の菌のジカルボキシイミド耐性変異は, os-1 ホモログの変異である可能性もある.

3 番目の演者, 大阪農技センターの岡田清嗣氏は, 灰色かび病 菌の薬剤耐性を精度高くモニターするための，新しい方法を紹 介した.これまでに報告されていたものよりも検出効率のよい, 灰色かび病菌の選択培地が考案され, その中にべノミル, プロ シミドン，そしてジエトフェンカルブを加えた培地平板を作製 した，更にこれを，新たにデザインされた胞子採集器の中に設 置することで，八ウス内での耐性菌の分布を的確にモ二ターす ることができた。

また, 胞子採集器を用いる代りに, 爪楊枝を使って, 病斑部 から菌の胞子を採取し，これを薬剤添加培地へ移植して，耐性 を検定する方法も紹介された。この方法であれば，特別な機械 も必要なく，栽培者自らが，耐性検定をすることも可能と思わ れた．同じ地域であっても，露地圃場やハウスによって，耐性 菌の分布状況が異なることも多いので,なるべく on site で耐性 菌の診断が出来ることが望ましい.

次いで, 農環研の石井英夫は, 殺菌剂耐性菌の遺伝子診断に ついて報告した。耐性菌の診断は現在，菌系生育試験や胞子発 芽試験のような生物検定法によっているが, 病原菌の種類に よっては, 多くの時間や労力がかかるなどの問題がある.この 点を改善するための一助として，RFLPやサザンハイブリダイ ゼーション, PCR, SSCPなどの手法が取り入れられた. 既に, 灰色かび病菌やナシ黒星病菌などのベンゾイミダゾール剂耐性 菌, ブドウやオオムギのうどんこ病菌のステロール脱メチル化 阻害剂（DMI）耐性菌の診断が試みられている.

これらの例では, 各々の薬剤の作用点タンパク質である, $\beta-$ チューブリンやステロール脱メチル化酵素の1アミノ酸置換 が，耐性をもたらすと考えられている，先に触れた，ストロビ ルリン耐性の機構が同様の, 1 アミノ酸置換による点突然変異 であるならば, うどんこ病菌, べと病菌のように培地上で人工 培養ができない, 取扱いの難しい病原菌の耐性検定も迅速かつ 容易なものとなろう。

最近各国で，炭疽病菌の一種である Colletotrichum acutatum の報告が相次いでいる，その理由は明らかでないが，ある種の 殺菌剂を，長年にわたって使用してきた影響かもしれない。ブ ドウ晚腐病では, 従来から知られていた Glomerella cingulata (=C. gloeosporiodes) のほかに, C. acutatum も病原となるこ とが最近示された。これら 2 種の病原菌は, ベンゾイミダゾー ル剤やジエトフェンカルブ剤に対する感受性が著しく異なるこ とから，それらの分布の違いによって，防除対応も変之る必要 がある.リボソーム RNA 遺伝子 (rDNA) や $\beta$-チューブリン 遺伝子の塩基配列の違いに基づいて, PCR で両菌を識別するこ とが可能であることから,この手法は畨場における菌の分布, 薬剤の生態影響などを調べる上で有効と考えられる.

Wayne Wilcox (コーネル大学) は, 圃場試験の結果に基づい て, DMI 耐性への対策についての考え方を述べた. ニューヨー ク州では, 1980 年代以降, トリアジメホンのブドウうどんこ病 : 対する効果が低い.しかし, 別の DMI であるミクロブタニル
に対する, 菌の感受性低下の程度は 6 倍程度に留まっている. 現在のところ, うどんこ病菌の感染初期にミクロブタニルを 3 回, その後イオウ剂を 3 回散布する方法が, 防除効果の点と耐 性菌対策としてべストであるという。また，STARをミクロブ タニルの後に使用するのもよいらしい.

リンゴ黒星病では, フェナリモル耐性菌の分布する圃場で, この薬剤の実用濃度と, その半分の濃度で比較試験がなされた. 耐性菌, 感受性菌のいずれに対しても, 防除効果は実用濃度が 優れたが，耐性菌を選抜してしまうという問題も残された。

日本でもリンゴ黒星病菌や, これと近縁のナシ黒星病菌に, DMI 耐性菌が低率で分布しているが, 薬剤の効果に影響した例 は, まだ確認されていない. 既に 15 年以上も使用されている薬 剂であるが，我が国ではキュウリやイチゴのうどんこ病など一 部を除けば, 耐性菌の発生事例も多くない.より優れた DMIを 求めて，今なお開発が進められている所以でもあろう。

最後の演者として, JA 全農営農・技術センターの天野徹夫氏 は，日本における耐性菌管理の実際の一部を紹介した。コムギ うどんこ病防除にトリアジメホンを散布した試験圃場では, 菌 の薬剂感受性が年次を追って低下した.コムギの収穫後に感受 性の回復は見られるものの, 完全ではなかった.これに基づき, 北海道では, DMI が年 1 回の使用に制限され, その結果, 耐性 菌による被害が回避された。薬剂感受性の継続的なモニタリン グと, その結果の適切な解釈が，有効に働いた良い例といえよ う. 最近は，新しい薬剂の開発，普及にあたって，菌の感受性 の標準値 (ベースライン) データが求められるようになってき ている。しかし，栽培現場で広く使用され，また耐性菌の存在 が疑われても，このべースラインデータが不備な場合も依然少 なくない. その薬剤が例外なく使用されていて，このデー夕を とることが不可能な場合もある.イチゴうどんこ病菌の DMI 耐性も同様で，この場合はやむなく，同じうどんこ病菌の寄主 となる，野生のシロバナノへビイチゴが使われた。

次いで, 栽培イチゴの菌の DMI 感受性と比較したところ, 卜 リフルミゾール，フェナリモル，ミクロブタニルいずれに対し ても, resistance factor はおよそ100であり，明瞭な交さ耐性が 認められた。他の多くの菌では, DMI 耐性のレベルは通常, あ まり高くないのであるが, うどんこ病菌ではなぜか高い場合が 多い. 作用点変異が耐性機構として重要な場合には耐性レベル が高く, 他の機構, 例えばステロール脱メチル化酵素の大量発 現などの場合には，耐性レベルが比較的低く，かつ不安定なの であろうか？ 講演では最後に，キュウリうどんこ病菌やべと 病菌の, ストロビルリン耐性菌の日本での発生事例が紹介され た. 現在, 耐性菌と感受性菌の fitnessに関する比較試験が行わ れ，その結果が待たれるところである.

以上が，我々のセッションで行われた講演の概略であるが, ポスターセッションでの発表も簡単に紹介しておきたい.

Margaret McGrath（コーネル大学）は，キュウリうどんこ病 菌の DMI 耐性菌が広く分布することを紹介した. 個人情報と して，アメリカでは，この菌のSTAR 耐性菌は，農家ではまだ 問題になっていない.しかし，この系統の薬剤を僅か数回使用 した, 露地の試験圃場から, 耐性菌が検出された。但し, 圑場 での薬剂の効果はあるという. 